\title{
Identification and intracellular localization of the unc-22 gene product of Caenorhabditis elegans
}

\author{
Donald G. Moerman, ${ }^{1}$ Guy M. Benian, ${ }^{2}$ Robert J. Barstead, Lawrence A. Schriefer, and Robert H. \\ Waterston \\ Department of Genetics, Washington University School of Medicine, St. Louis, Missouri 63110 USA
}

\begin{abstract}
The unc-22 gene is one of a set of genes identified using classical genetics that affect muscle structure and function in the free-living nematode Caenorhabditis elegans. Since cloning the unc-22 gene by transposon tagging, we have used conventional techniques combined with a set of $\mathrm{Tc} 1$ transposon insertion alleles to characterize the gene and its products. The gene extends over more than $20 \mathrm{~kb}$ of genomic sequence and produces a transcript of approximately $14 \mathrm{~kb}$. A polyclonal antibody raised against an Escherichia coli $\beta$ galactosidase-unc-22 fusion protein recognizes a polypeptide in nematode extracts that is between 500,000 and 600,000 daltons and labels the muscle $A$-band in indirect immunofluorescent microscopy. The Tc1-induced alleles have been used at every stage to verify these conclusions. The Tc1 insertions are spread over much of the region that contributes to the mature transcript; in most alleles, Tc1 sequences are incorporated into a composite unc-22-Tc1 transcript. The large protein is either absent or severely reduced in amounts in the mutants. In one case, a truncated polypeptide was also identified. The location of the protein in the A-band, along with earlier genetic data, suggests that the unc-22 product may interact with myosin to regulate its function.
\end{abstract}

[Key Words: Muscle structure; unc-22; myosin; transposon; nematode]

Received July 6, 1987; revised version accepted November 4, 1987.

The discovery of mutator strains of Caenorhabditis elegans in which the element Tc1 transposes at high frequencies has made possible the recovery of DNA sequences for genes without prior knowledge of the protein product (Moerman and Waterston 1984; Eide and Anderson 1985; Greenwald 1985; Moerman et al. 1986). Among the first genes isolated via Tc1 tagging was the unc-22 locus (Moerman et al. 1986), which is a particularly frequent target of the element and has been used extensively in characterizing the mutator activities. The unc-22 locus is also of interest as one of more than 25 genes implicated in normal muscle formation in $C$. elegans (Brenner 1974; Waterston et al. 1980; Zengel and Epstein 1980). This set of genes has been studied intensively, and the genes for many of the major components of the myofilament lattice have been identified, including myosin heavy-chain isoforms (Epstein et al. 1974; MacLeod et al. 1977b; Karn et al. 1983), actins (Landel et al. 1984), and paramyosin (Waterston et al.

\footnotetext{
'Present address: Department of Zoology, University of British Columbia V6T 2A9 Canada.

${ }^{2}$ Present address: Department of Pathology, Emory University School of Medicine, Atlanta, Georgia 30322 USA.
}

1977; H. Kagawa and J. Karn, pers. comm.). The product of the unc-22 gene, however, remained unknown.

Among the muscle-affecting genes, unc-22 is particularly intriguing because of its unusual phenotype. $\mathrm{Mu}$ tant alleles of the locus lead to varying degrees of impaired movement and muscle disorganization (Moerman 1980; Waterston et al. 1980). Weak alleles have little effect on movement or muscle structure. Strong alleles lead to almost complete paralysis of adult animals and to abnormal muscle structure in which thick and thin filaments, though present in normal quantities, are not in their normal register. All alleles, however, produce a nearly constant, subcellular twitch in all the body wall muscle cells. This phenotypic feature otherwise results only from rare alleles of the unc-54 myosin heavy-chain gene (MacLeod et al. 1977a; Dibb et al. 1985) and from one allele of $1 e v-11$ (Lewis et al. 1980). Whether the twitch represents an unregulated contraction or relaxation is unclear, but the twitch is exacerbated by choline agonists (Moerman and Baillie 1979).

Genetic analysis has yielded several insights into the nature of the gene and its function. The gene is an unusually large mutational target (Zengel and Epstein 1980), and intragenic recombination frequencies for alleles at opposite ends of the gene are similar to or higher 
than frequencies seen for the most distant allelic pairs of the unc-54 gene (Moerman and Baillie 1979; Waterston et al. 1982), which encodes the 228,000-dalton myosin heavy chain (Karn et al. 1983). Thus, the gene is likely to be much larger than average. Most alleles are conditionally dominant, that is, heterozygous unc-22/ + animals move normally and have normal muscle structure but can be induced to twitch violently in solutions of choline agonists (Moerman and Baillie 1979). As this dominance is shown even by likely null alleles, including an amber allele $s 32$ and deletion alleles, the unc-22 gene probably encodes a protein required stoichiometrically. Most intriguing of all, reversion analysis of unc-22 alleles revealed that certain missense alleles of the myosin heavy-chain gene unc-54 can suppress the unc-22 phenotype (Moerman et al. 1982). Not only is the twitch suppressed and motility partially restored, but muscle structure is also improved. Sequence analysis of the unc-54 suppressors showed that all of these mutations lie in the region coding for the myosin head; several are located near the nucleotide binding domain, and others are near the conserved thiol domain (Dibb et al. 1985; J. Kiff, D.G. Moerman, and R.H. Waterston, unpubl.).

In this study, we have used the recently obtained DNA clones from the unc-22 region (Moerman et al. 1986) to investigate the molecular organization of the gene and the nature of its product. In addition, because unc-22 is a frequent target of the C. elegans var. Bergerac mutator system, and because the mutator-induced alleles are generally intermediate in strength, we examined several mutator-induced alleles to determine the nature of the mutations and their effects on unc-22 gene expression.

Our results show that the unc-22 gene extends over more than $20 \mathrm{~kb}$, that Tc1 insertions probably account for all the mutator-induced alleles of this set, and that the insertions occur throughout much of the unc-22 transcribed region. In addition, a $14-\mathrm{kb}$ transcript has been identified, which is increased in size in the Tc1 mutants by the inclusion of the Tc1 sequence. The polypeptide identified with an antibody produced to a fusion protein is larger than rabbit nebulin, which has been reported to be approximately 500,000 daltons in size (Wang and Williamson 1980). This protein is absent in amber and deletion alleles and is altered in size in a Tc1induced allele. The unc-22 polypeptide in wild type is located in muscle cells and is apparently cell autonomous. Its colocalization with myosin at the light microscopic level in several strains, together with the previous genetic data, suggests that the unc-22 protein interacts with components of the thick filament.

\section{Results}

Sequences important for unc-22 expression extend over more than $20 \mathrm{~kb}$

The region of genomic DNA cloned in previous work extends over $70 \mathrm{~kb}$ (Coulson et al. 1986; A. Coulson and J. Sulston, pers. comm.), of which more than $30 \mathrm{~kb}$ has been recovered in phage clones (Fig. 1; Moerman et al. 1986). Various unc-22 alleles were screened for rearrangements within this region to help define the extent of the unc-22 gene. The positions of the deficiency $s D f 19$ (Rogalski and Baillie 1985), which by genetic criteria breaks within the genes, and two Tc1 insertions, st136::Tc1 and st137::Tc1, were determined previously (Moerman et al. 1986). Several diepoxybutane-induced alleles were found to have small deficiencies to the right of the st136::Tc1 position (C. Trent, pers. comm.). In addition, we examined 12 more mutator-induced unc-22 alleles for changes in restriction fragments in the unc-22 region. All 12 alleles showed alterations in their hybridization patterns; in each mutant, a change consistent with a single insertion of $1.6 \mathrm{~kb}$, the size of Tc1 (Rosenzweig et al. 1983), was found.

The 12 different Tc1 insertions were placed into at least 10 different sites by analyzing the patterns produced on Southern transfers of DNA from each allele digested with four different restriction enzymes (Fig. 1). For example, in DNA from the st140::Tc1 allele, the 3.5-kb SacI fragment of the wild type has been replaced by a $5.1-\mathrm{kb}$ fragment (Fig. 2). A weak signal is present in this DNA at $3.5 \mathrm{~kb}$, but this is presumed to be the result of somatic excision of Tc1 (Emmons and Yesner 1984). The $s t 181:: T c 1$ allele affects the same SacI fragment, but st 140::Tc1 and st181::Tc1 are clearly at different sites as in st 140 DNA the $0.4-\mathrm{kb} B g / \mathrm{II}$ fragment is replaced with a $2.0-\mathrm{kb}$ fragment whereas in the st181 DNA the adjacent 3.4-kb BglII fragment is altered (data not shown). Data for two additional alleles, st185::Tc1 and st139::Tc1, are also shown (Fig. 2). Eleven of the insertions are distributed over $17 \mathrm{~kb}$. The twelfth insertion, the $s t 139:: T c 1$ allele, lies about $12 \mathrm{~kb}$ outside this group. To verify that this insertion indeed represents the relevant sequence change producing the Unc-22 phenotype, we recovered a mutator-induced revertant of st139::Tc1; its restriction pattern is indistinguishable from that of wild type (Fig. 2). The st139::Tc1 allele is unusual in that it results in such a weak phenotype that it is necessary to use the choline agonist nicotine to score the homozygote reliably. The leftmost-located Tc1 insertion st185::Tc1, which lies under the $s D f 19$ deficiency, results in a weak phenotype, intermediate between st139::Tc1 and the other Tc1 alleles.

\section{unc-22 produces a $14-\mathrm{k} b \mathrm{mRNA}$}

To determine what transcripts might arise from the region defined by the rearrangements, we probed Northern transfers of size-fractionated total RNA with various radiolabeled fragments from the genomic clones. A $1.6-\mathrm{kb}$ RNA species was recognized only by the $4.6-\mathrm{kb} S a c I$ fragment that extends to the left of the $s D f 19$ deficiency break point (data not shown). No probes from other regions recognized this RNA, so we considered that it was likely to be the product of another gene. A much larger species, estimated to be $14 \mathrm{~kb}$ using single-stranded DNA markers (see Fig. 3), also hybridized with the 4.6$\mathrm{kb}$ SacI fragment, as well as with probes throughout the 


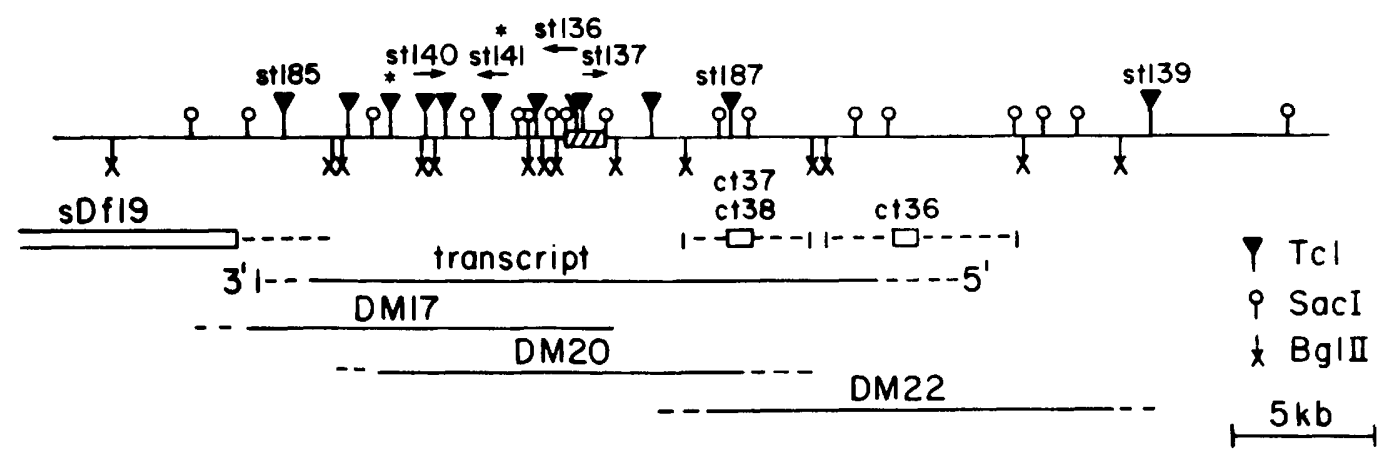

unc-22 region

Figure 1. The unc-22 region and sites of Tc1 insertion. The genomic segment containing the unc-22 gene is shown, along with several DNA rearrangements that define its extent. Three $\lambda$ clones, which together span most of the region, are also shown. The minimum region contributing to the transcript is indicated, and the direction of transcription, as determined using single-stranded probes, is from right to left. The positions of the large deficiency $s D f 19$ (Rogalski and Baillie 1985; Moerman et al. 1986) and three smaller deficiencies, ct36, ct37, and ct38 (C. Trent, pers. comm.), are shown as open boxes. The break point of sDF19 was used to show that the orientation of the physical map to the genetic map is as depicted (Moerman et al. 1986). The approximate position of 14 Tc1 insertions that result in the Unc-22 phenotype are indicated by triangles. The asterisks above two of the triangles indicate that two independent insertions have been localized within the interval. The order and approximate sizes of the SacI fragments, as well as the order of the unc-22::Tc1 alleles, are from right to left: $7.2 \mathrm{~kb}$ (st139), $1.0 \mathrm{~kb}, 0.9 \mathrm{~kb}, 4.3 \mathrm{~kb}, 1.1 \mathrm{~kb}, 3.7 \mathrm{~kb}, 0.9 \mathrm{~kb}$ (st187), $3.9 \mathrm{~kb}$ (st188), $1.7 \mathrm{~kb}$ (st137, st136), $0.3 \mathrm{~kb}, 1.0 \mathrm{~kb}$ (st184), $0.2 \mathrm{~kb}, 1.5 \mathrm{~kb}$ ([st141, st191]), $3.5 \mathrm{~kb}$ [st181, st140, (st186, st182)], $4.6 \mathrm{~kb}$ (st183 and st185). The orientation of the Tc1 insertion, where known, is shown by an arrow. The striped box denotes the 1.9 -kb SacI fragment that was subcloned into the expression vector $\lambda \mathrm{RB}$ (R.J. Barstead and R.H. Waterston, unpubl.).

region containing the majority of the insertion sites. The rightmost fragment tested that gave a positive signal was the $1.1-\mathrm{kb}$ SacI fragment. The adjacent $4.3-\mathrm{kb}$ SacI fragment yielded no hybridization signal. Fragments farther to the right were not tested. The region covered by these fragments and thus contributing to the $14-\mathrm{kb}$ transcript extends over about $20 \mathrm{~kb}$. Single-stranded DNA probes showed that the orientation of the transcription unit is from right to left on the conventional genetic map.

To confirm that the 14-kb transcript is the product of the unc-22 locus, we also examined RNA from several unc-22 mutants that might be expected to have altered mRNA levels or sizes. Amber alleles are known in other genes to reduce the steady-state mRNA levels (Losson and LaCroute 1979; Brown et al. 1982), and one unc-22 amber allele, s32, has been identified (Moerman 1980). In RNA from $s 32$ homozygotes, the signal from the $14-\mathrm{kb}$ band was reduced markedly compared to wild type when hybridized with an unc-22 region probe; in control experiments using an unc-54-specific probe against the same filter, the signal from the myosin message was similar between the wild-type and $s 32$ lanes (Fig. 3).

As insertion of transposable elements into the transcribed portion of a gene has been shown to affect the transcript in any of a variety of ways (Doring et al. 1984; Levis et al. 1984; Pirrotta and Brockl 1984; Rowland and Strommer 1985; Zachar et al. 1985), we also examined RNA from several of the Tc1-induced alleles. These include st139::Tc1, st137::Tc1, st136::Tc1, st141::Tc1, $s t 140:: T c 1$, and $s t 185:: T c 1$, which span the region of interest (Fig. 1). When hybridized with probes from unc-22
(Fig. 4a), in five of the six cases, the hybridizing transcript appeared slightly larger than that in wild type, but of similar abundance. Because an increased size might result from incorporation of $\mathrm{Tc} 1$ sequences into the transcript, similar Northern transfers were hybrdized with a Tc1 sequence. In the wild type, no RNA in this region of the transfer hybridized with $\mathrm{T} c 1$.

Both orientations of Tc1 insertion are represented in these five alleles. The st136::Tc1 and st $137:: T c 1$ alleles have Tc1 inserted in opposite orientations (Moerman et al. 1986). Hybridization of Northern transfers with single-stranded Tc1 probes showed that st140::Tc1 has the same orientation as $s t 137:: T c 1$ and that st141::Tc1 has the same orientation as st136::Tc1. The orientation of the st185::Tc1 allele was not determined.

The only allele of the six that tested positive with unc-22 probes but negative with the Tc1 probe was st139::Tc1. This is the very weak allele whose site of Tc1 insertion is well to the right of the position of the other DNA rearrangements associated with unc-22 phenotypes.

\section{The unc-22 protein is larger than 500,000 daltons}

To determine the size of the unc-22 protein product and its location in muscle, we raised antibodies against a polypeptide produced by the fusion of unc-22 sequences to the $\beta$-galactosidase gene of Escherichia coli. Limited sequencing of a region near the st136::Tc1 insertion site revealed an open reading frame extending through a SacI site that would remain in frame when ligated to the SacI site within the $\beta$-galactosidase gene (data not shown). We inserted the corresponding $1.9-\mathrm{kb}$ unc-22 SacI frag- 


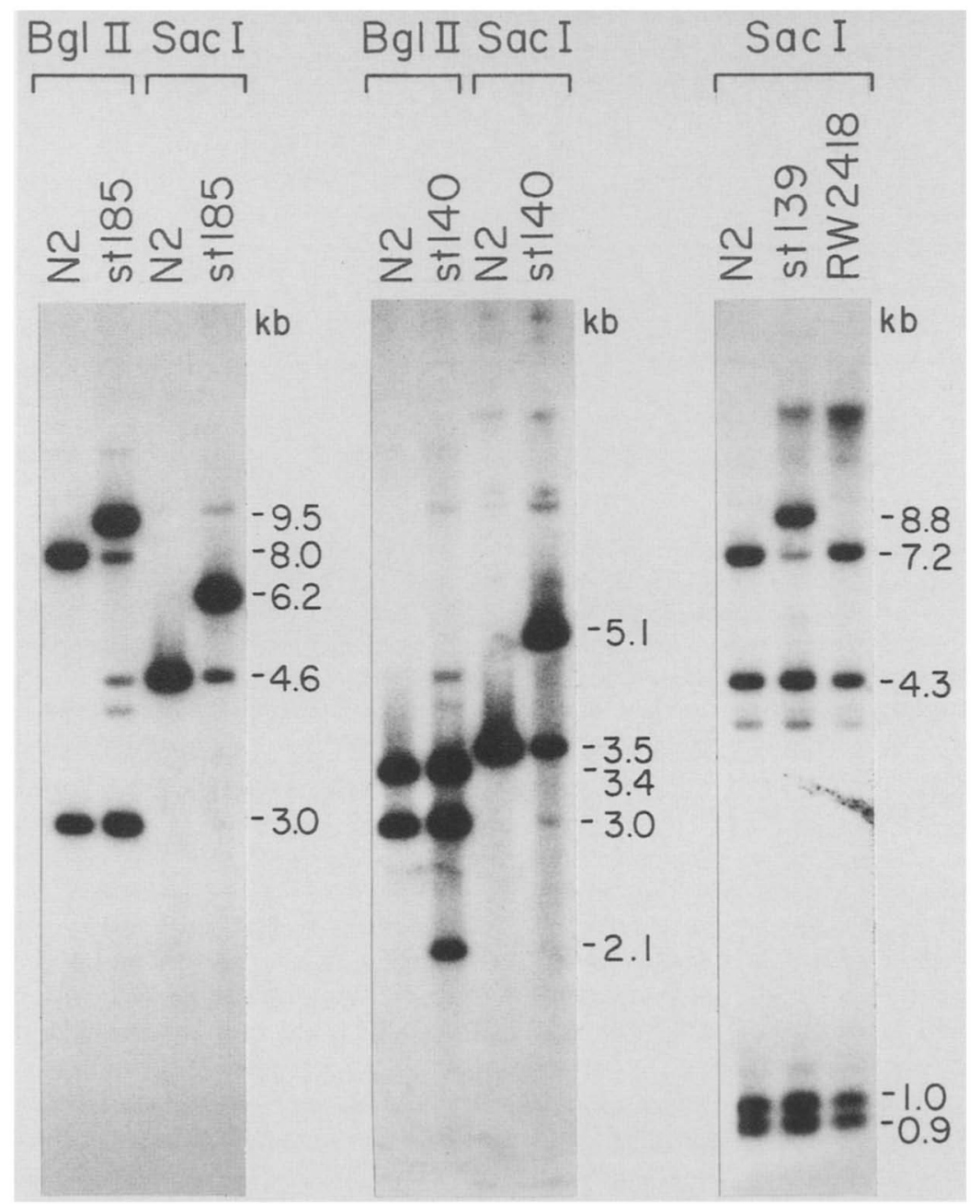

Figure 2. Spontaneous unc-22 alleles isolated in mutator background have Tc1 insertions in the unc-22 region. DNA from each of the 12 mutator-induced unc-22 alleles was isolated and compared to wild-type DNA by Southern blot analysis. By using the $\lambda$ clones in Fig. 1 as probes, each mutant strain was shown to contain an insert of $1.6 \mathrm{~kb}$ in single SacI and Bglll fragment. Once a mutation was localized to a small region, the appropriate SacI or BglII fragment spanning the insertion site was used as a probe to confirm this assignment. The simpler pattern obtained allowed unambiguous interpretation of the results. Shown are two examples, st185 and st140, where we have probed digested DNA from strains containing these mutations with a Sacl fragment spanning the Tc1 insert, and one example, st139, where we have used a $\lambda$ clone. The st 185 mutation was probed with the left-most $4.6-\mathrm{kb}$ Sacl fragment, st140 was probed with the $3.5-\mathrm{kb}$ SacI fragment adjacent to the $4.6-\mathrm{kb}$ fragment, and st 139 was probed with $\lambda$ DM 22 containing the rightmost region of the gene. In all three cases, a band $1.6 \mathrm{~kb}$ larger than the corresponding wild-type band was detected. Weaker hybridization at the position of the wild-type band was also seen, which was probably a result of somatic excision, a characteristic of all Tc1 insertions so far identified. Similar results were obtained for the other 11 mutants described in Fig. 1. A revertant of st139::Tc1 was recovered and included in the analysis. The revertant, RW2418, has lost the 8.8-kb SacI hybridizing band and regained the wild-type 7.2-kb hybridizing band.

ment in the desired orientation into a modified $\lambda \mathrm{gt} 11$ vector that has a unique SacI site within the $\beta$-galactosidase gene (Young and Davis 1983; R.J. Barstead and R.H. Waterston, unpubl.). When $\beta$-galactosidase expression was induced, a fusion peptide of about $155 \mathrm{kD}$ appeared in the $\lambda$ lysogens, the size expected if the open reading frame was maintained across the entire $1.9-\mathrm{kb}$ SacI fragment, with a subsequent out-of-frame fusion to the remainder of the $\beta$-galactosidase sequence (data not shown).

To obtain antiserum, the polypeptide was partially purified and injected into rabbits. The resultant serum, called R11-3, was adsorbed extensively against fulllength $\beta$-galactosidase and used against Western transfers. The antiserum reacted strongly against the $155-\mathrm{kD}$ protein in $\lambda$ lysogens (data not shown) and with a very large protein or proteins in either 2-aminoethanol or SDS-soluble proteins from $C$. elegans wild-type animals (Fig. 5). The signal, depending on the preparation, was either a single band or a closely spaced doublet. Extrapolating from the mobilities of myosin heavy-chain $(225,000$ daltons; $\mathrm{Rf}=0.66)$ and rabbit nebulin $(500,000$ daltons; Wang and Williamson 1980; $\mathrm{Rf}=0.22$ ) markers, the wild-type protein, or proteins, was esti- 


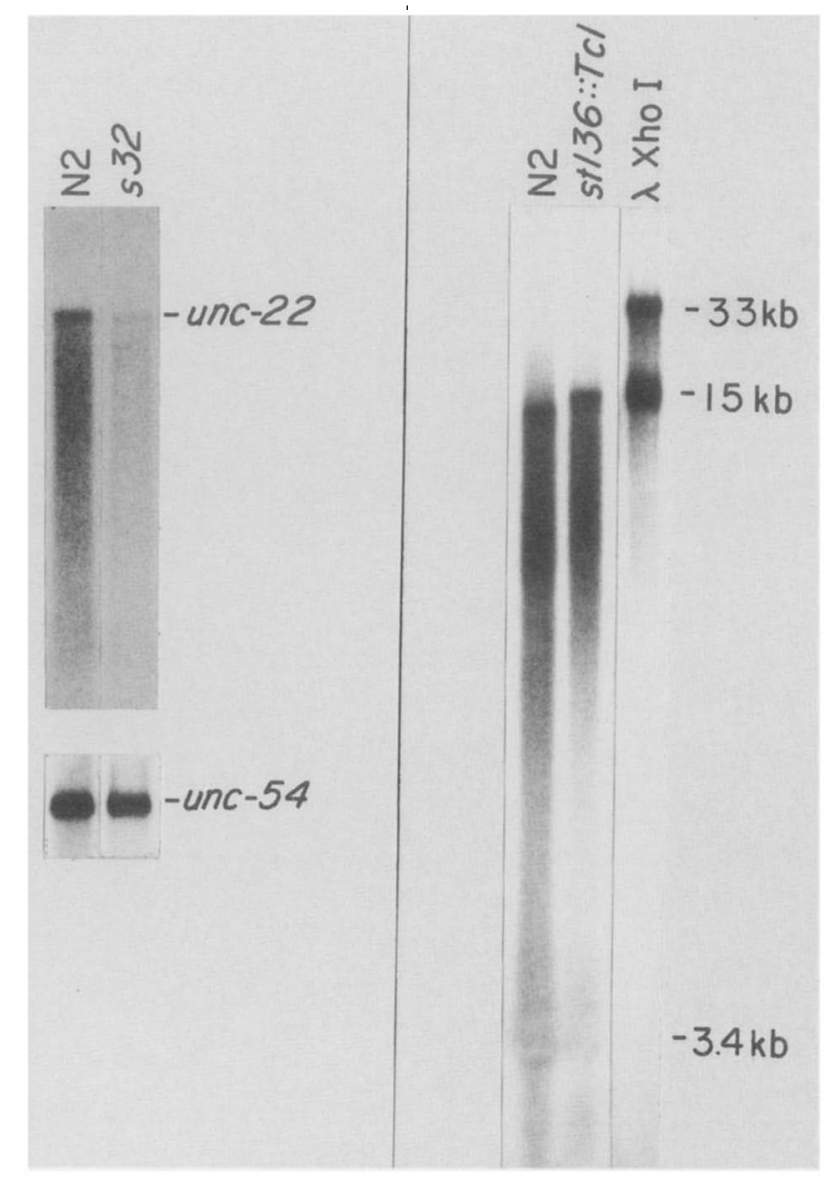

Figure 3. unc-22 encodes a $14-\mathrm{kb}$ message. Total RNA isolated from the indicated strains was examined by Northern analysis, as described in Materials and methods. The filter on the left shows a comparison of $\mathrm{N} 2$ to an unc-22 amber allele, s32, after hybridization with $\lambda D M 17$. In $\mathrm{N} 2$, a prominent band near the top of the filter is observed, which has a dark smear below it. In $s 32$, this band and smear are greatly reduced. Hybridization of this filter with an unc-54-specific probe shows that the $6.1-\mathrm{kb}$ myosin heavy chain message is not degraded and that the RNA amounts in each lane are comparable. The filter on the right has RNA from N2 and the mutant strain $s t 136:: T c 1$, as well as single-stranded DNA size markers from $\lambda$ phage. The probe in this case was again $\lambda D M 22$. By comparison of the high-molecular-weight band in $\mathrm{N} 2$ to the $\lambda$ size markers, the steady-state unc-22 message is approximately $14 \mathrm{~kb}$ in size. The unc-22::Tc1 strain produces an even larger message (see text and Fig. 4).

mated to have a molecular weight of 500,000 to 600,000 $(\mathrm{Rf}=0.16)$.

Again, to ensure that the reactive polypeptide was indeed the product of the unc-22 locus, we examined mutant alleles in which we could anticipate that the amount or size of the product would be altered. No signal was detected from homozygotes of the deficiency allele, ct37 (Fig. 5; see also Fig. 1 for the location of $c t 37$ ). In $s t 136:: T c 1$ extracts, a closely spaced doublet of lower molecular weight and reduced intensity was observed (Fig. 5). After an exposure of the blot approximately five times longer than that shown in Fig. 5, a weak signal was observed in the $s t 136:: T c 1$ extracts at the same mobility as the wild-type signal. Even after this longer exposure, no signal was detected from the ct37 extracts.

The unc-22 protein is located in the A-bands of striated muscle

After adsorption, the R11-3 serum was also used to determine the in vivo location of the unc-22 protein. The antiserum reacts specifically, by indirect immunofluorescence, with $\mathrm{A}$ bands of wild-type muscles, not only including the body wall muscles (Fig. 6) but also the anal, vulval, and pharyngeal muscles (data not shown).
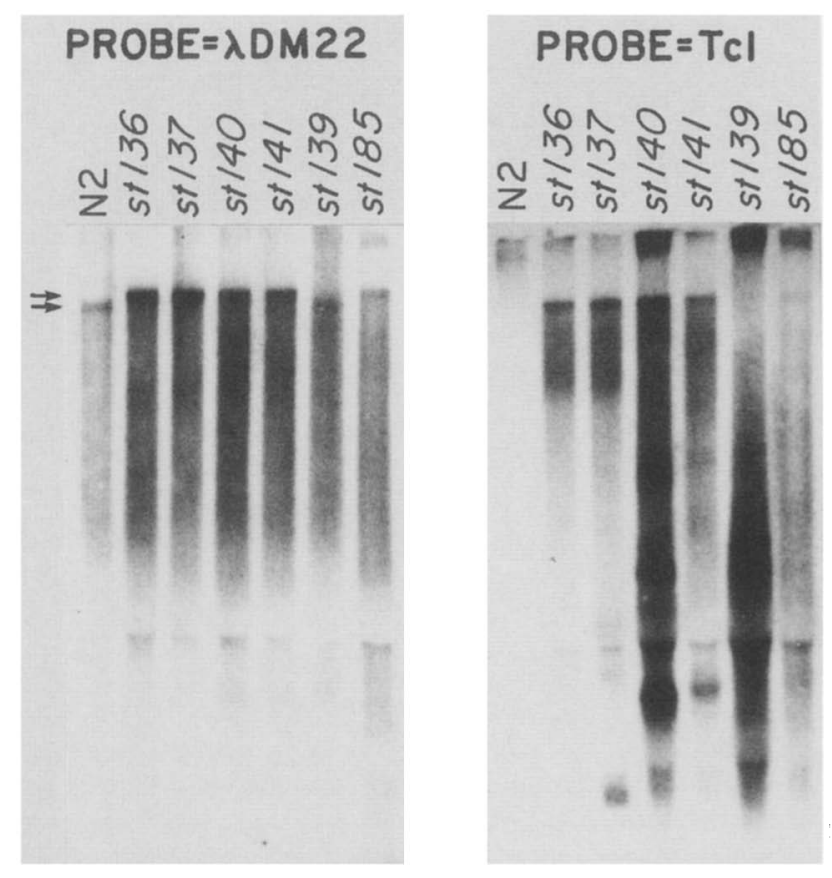

Figure 4. Hybrid unc-22-Tc1 transcripts from unc-22::Tc1 insertion alleles. Duplicate Northern filters of total RNA were prepared from the wild-type $\mathrm{N} 2$ strain and six unc-22::Tc1 strains and hybridized with either $\lambda \mathrm{DM} 22$ or Tc1. The unc-22 probe detected a single high-molecular-weight band, but in five of six mutant strains the hybridizing band was even larger than in N2. However, the st139::Tc1 strain, which has the most 5' Tc1 insert, showed a band at the same level as in N2. The higher-molecular-weight band observed in the five mutant strains using an unc-22 probe was also observed with a Tc1 probe. In contrast, the N2 and st139::Tc1 strains did not have any signal in this region of the filter. Less RNA was loaded for the $s t 185:$ Tc1 strain and presumably accounts for the reduced signal. Additional bands and smears observed in the st140, st141, st139, and st183 lanes relative to the N2, st136, and st137 lanes on the Tc1-probed filter correlate with strain background. The first four alleles mentioned are in strains with active mutators, and these unc-22 alleles are all unstable. N2 is a nonmutator strain, whereas st 136 and st 137 were moved from mutator-active to mutator-inactive backgrounds [see Moerman and Waterston (1984) for details on the genetics of mutator strains]. Whether these extra hybridizing bands observed with a Tc1 probe are due to RNA or contaminating DNA has not been determined. 


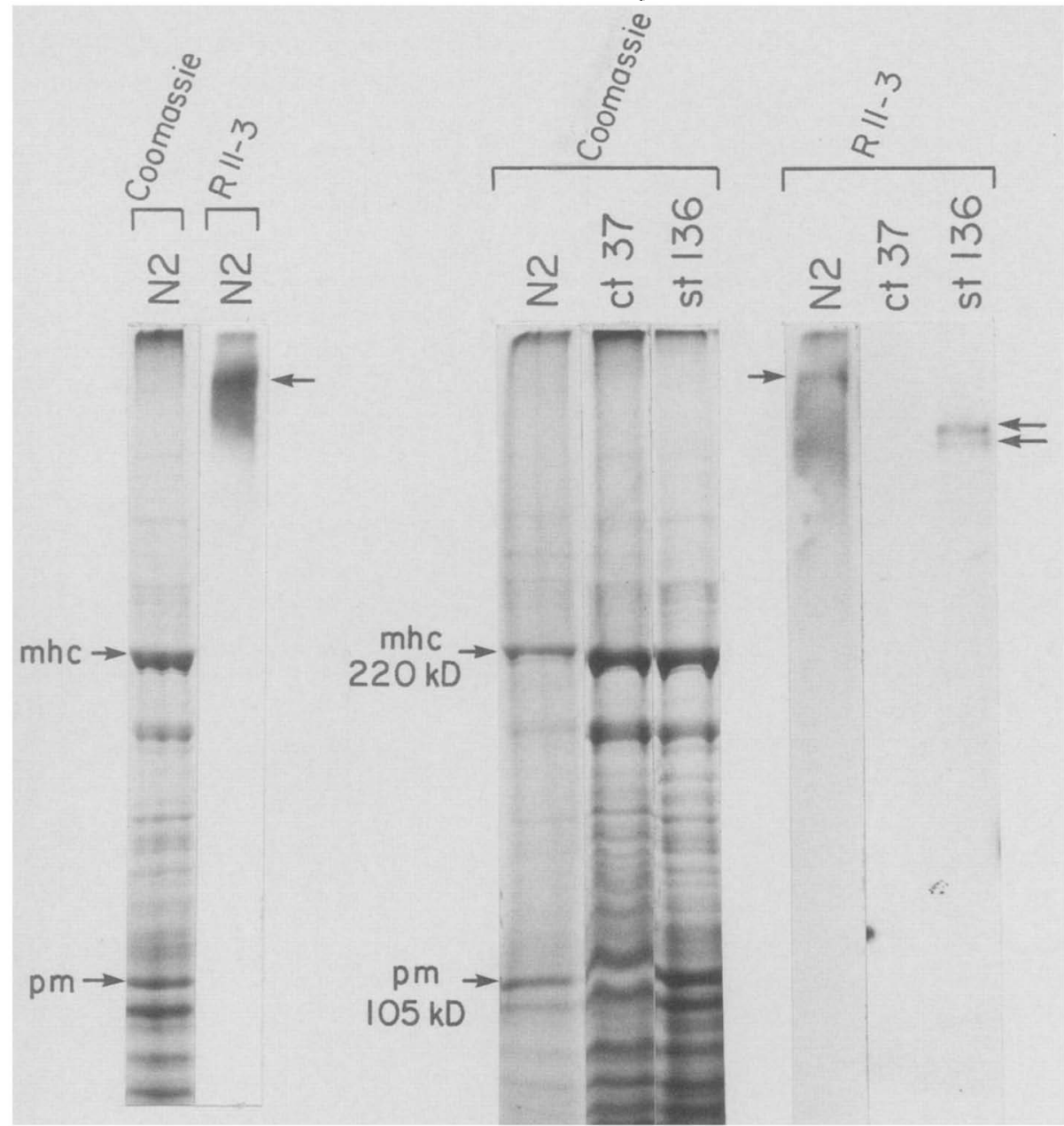

Figure 5. Antiserum to an unc-22- $\beta$-galactosidase fusion polypeptide identifies a polypeptide in C. elegans that is larger than 500,000 daltons. Rabbit antibodies were generated to an unc-22- $\beta$-galactosidase fusion polypeptide (see text for details), and the resulting serum, R11-3, was absorbed against $\beta$-galactosidase before use. Total $C$. elegans protein extracts, prepared as described in Materials and methods, were separated on a polyacrylamide gel and either stained with Coomassie blue or transferred to nitrocellulose, reacted with the R11-3 antiserum and ${ }^{125} \mathrm{I}$-labeled protein A, and visualized after autoradiography. The molecular weight markers shown here are paramyosin $(\mathrm{pm})$ at $105 \mathrm{kD}$ and myosin heavy chain $(\mathrm{mhc})$ at $220 \mathrm{kD}$. The left pair of panels shows that in wild type animals the antisera react with a large protein or proteins of $\sim 500 \mathrm{kD}$. Although not visible here, in some extracts a faint band, corresponding to the band detected with the antiserum, can also be obsrved after Coomassie blue staining. The panels on the right demonstrate that the antibody reactive band is either absent or altered in unc-22 mutants. Mutants bearing the unc-22 internal deficiency $c t 37$ lack this large protein; no signal can be detected even after prolonged exposure. From a st136::Tc1-bearing strain, a shorter polypeptide that runs as a doublet is detected with the R11-3 antiserum. In some preparations, the reactive species in N2 can sometimes be a doublet.

No signal was observed in any of these muscle cells in animals treated with the preimmune serum. In the body wall muscles, the R11-3 reactive region appears to be nearly coextensive with the region stained by an unc-54specific monoclonal antibody. This colocalization is observed even in a mutant where the unc-54 myosin is present but is not part of a normal A-band (Fig. 7).

Mutant animals were again used to determine the contribution of the unc-22 gene to the observed signal (Fig. 6). In ct37 animals, the antibody staining is drastically reduced in the body wall, vulval, and anal muscles. In contrast, the pharyngeal signal is identical to wild type. The slight residual staining of the body wall muscles in wild type is confined to narrow strips between each row of dense bodies. The pattern obtained with the anti-unc-54 antibody is abnormal, but the signal remains strong. Similar results were obtained with the antibody when used on most $s t 136:: T c 1$ animals.

\section{unc-22 protein expression is cell autonomous}

Because Tc1 is known to excise somatically (Emmons and Yesner 1984; Eide and Anderson 1985), we elected to see if we could identify animals in which one or a few muscle cells contained normal or nearly normal levels of the antibody reactive protein. In previous work we had obtained a strain containing st $136:: T c 1$ in which germ line excision is exceedingly rare $\left(<10^{-7}\right)$, yet somatic excision, as judged by Southern analysis of exponentially 


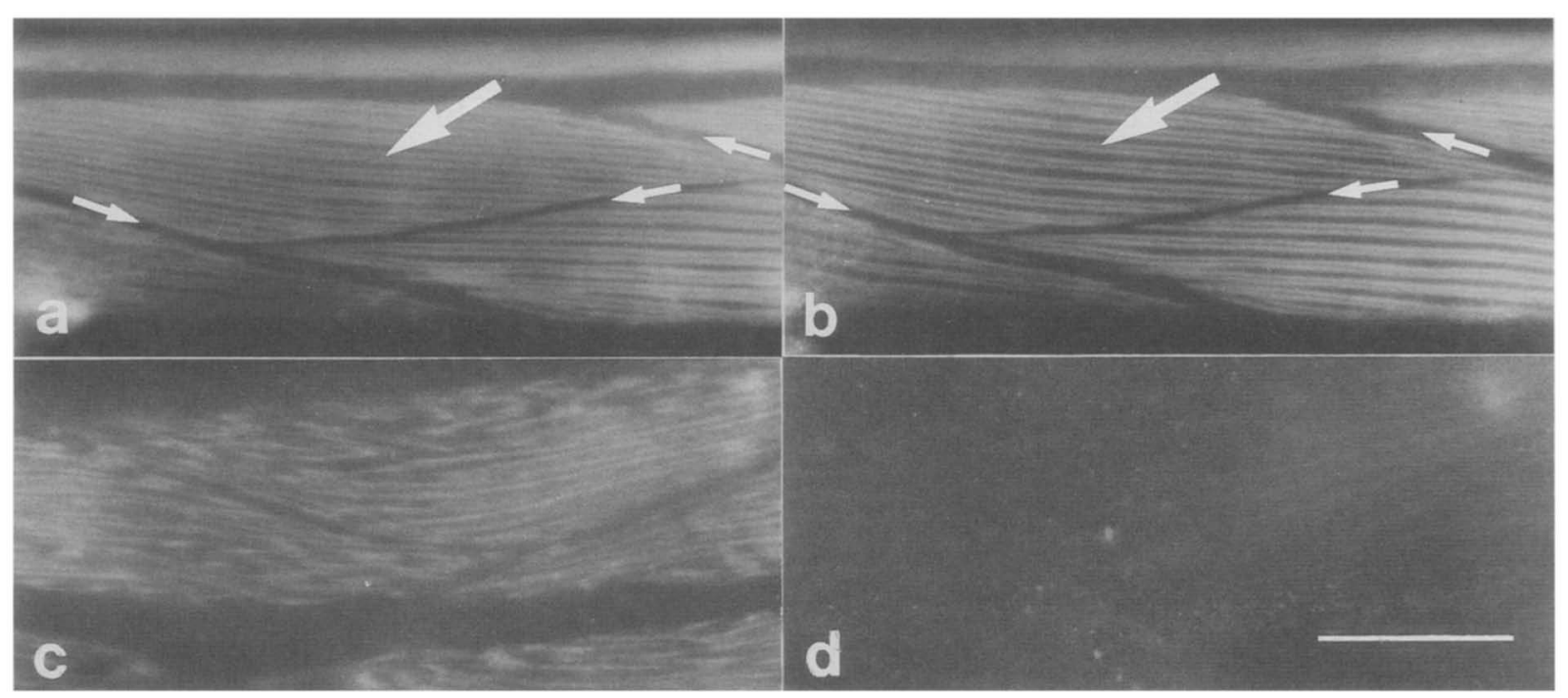

Figure 6. Subcellular localization of the unc-22 protein relative to the unc-54 myosin heavy chain protein. Wild-type $(a, b)$ or unc-22(ct37) mutant animals $(c, d)$ were prepared for immunofluorescence, as described in Francis and Waterston (1985) and Materials and methods. They were then double stained with the monoclonal antibodies DM28.2 (Miller et al. 1983) and DM5-8, which are specific for the unc-54 myosin heavy chain protein $(a, c)$ and with the R11-3 serum $(b, d)$. The R11-3 staining in wild type $(b)$ is localized to the same region as the unc- 54 myosin $(a)$. Overall, the A-bands are severely disorganized in the mutant, as shown by the myosin distribution $(c)$, and the Rl1-3 staining is greatly reduced compared to wild type $(d)$. The residual signal in the mutant is midway between the rows of dense bodies (not stained). The large arrows in $a$ and $b$ point to the center of the same A-band. Smaller arrows indicate the cell boundaries. The longitudinal axis of the nematode is horizontal. Bar, $20 \mu \mathrm{m}$.

growing populations, is as high as that in mutator strains (Moerman and Waterston 1984; Moerman et al. 1986). In fragments prepared from random populations of this $s t 136:: T c 1$ strain, we observed rare specimens with muscle cells that had strong R11-3 reactivity distributed within the cells in a striated pattern (Fig. 8). Within the same fragments, cells were also present that did not stain with the antibody, and the limits of the staining clearly corresponded to muscle cell boundaries. As a control, the same animals were also stained with the unc-22-specific antibody, and all cells stained. In addition, no cell-limited staining was ever observed in wild-type animals prepared the same way. In cells that reacted with both antibodies, the unc-54 and unc-22 proteins appear to be colocalized even in instances where the A-bands are somewhat disorganized (Fig. 8).

\section{Discussion}

Genetic studies indicated that unc-22 might be an unusually large gene, both from the frequency of mutation and the recombinational distances between unc-22 alleles. Our molecular studies confirm these earlier inferences. The genomic region comprising the unc-22 gene must be at least $20 \mathrm{~kb}$, based on the rearrangements analyzed. The major cluster of Tc1 insertion sites is distributed over $17 \mathrm{~kb}$, and the diepoxybutane-induced deletions extend the region a minimum of another $3 \mathrm{~kb}$. DNA throughout the $20-\mathrm{kb}$ region contributes to the es-

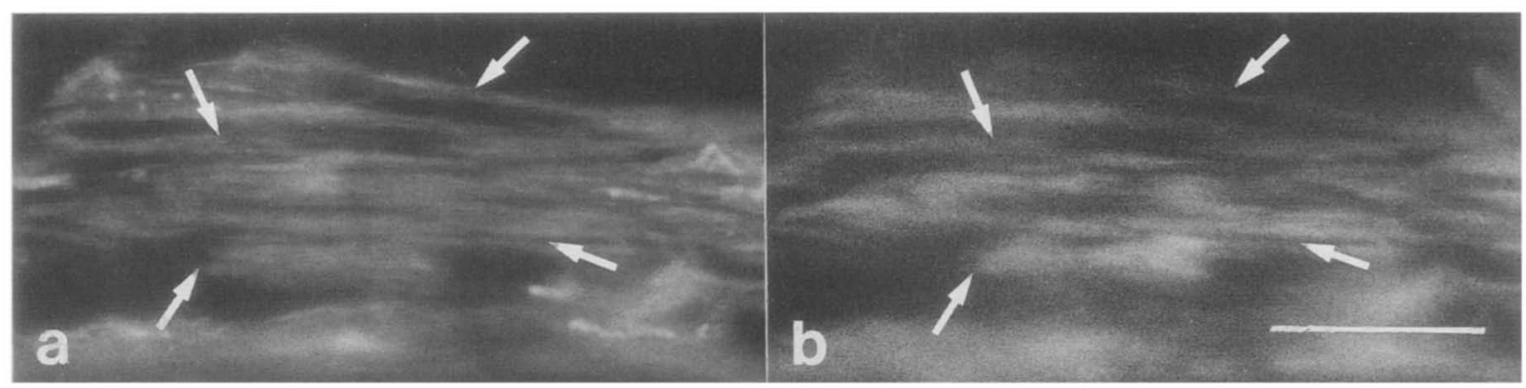

Figure 7. Colocalization of unc-22 and unc-54 proteins in a thick filament mutant. Shown is an animal homozygous for the dominant missense allele unc-54(st273) stained with DM5-8 (a), a monoclonal antibody specific to the unc-54 protein and R11-3 (b), a polyclonal antibody that reacts with the unc-22-encoded protein (see Dibb et al. 1985 for a fuller description of this class of unc-54 mutation|. Homozygotes of st273 have severely disorganized thick filaments, as shown in $a$ using the unc-54-specific monoclonal antibody. The unc-22 R11-3 serum reveals a similar subcelluar staining pattern $(b)$ to that observed in $a$, which indicates that even in cells with disorganized A-bands the unc-22 protein and myosin are colocalized. Arrows in $a$ and $b$ point to similar position. Bar, $20 \mu \mathrm{m}$. 


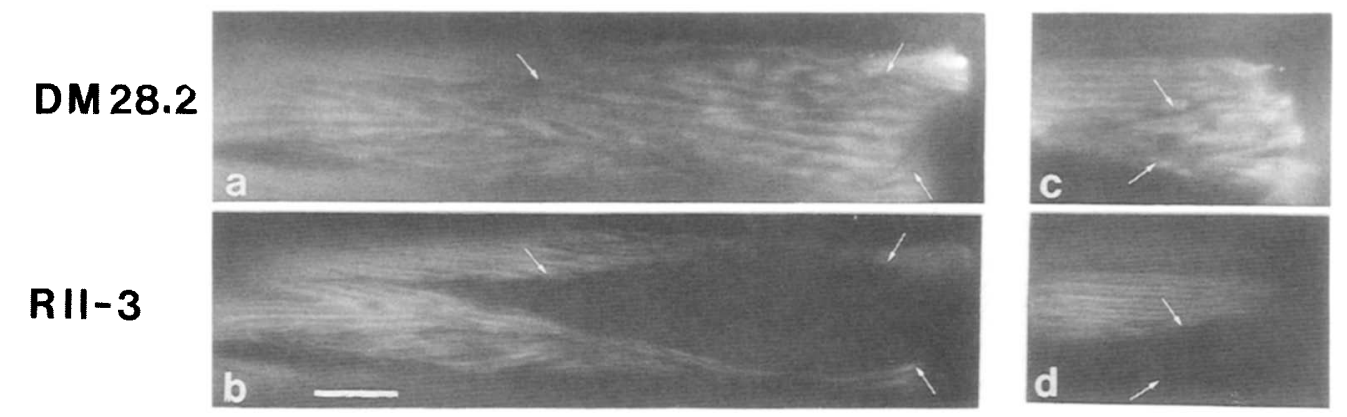

Figure 8. The unc-22 gene product is cell autonomous. Mosaic animals were detected when R11-3, the polyclonal antibody to the unc-22 protein $(b, d)$ and DM28.2, a monoclonal antibody to the major myosin heavy chain $(a, c)$, were used against unc-22(st136::Tc1) animals. (a) Three body wall muscle cells stained with the myosin antibody; $(b)$ the same three cells as in $a$ treated with the unc-22 antibody; $(c)$ the ends of two body wall muscle cells reacted with the myosin antibody; $(d)$ the same muscle cells as in $c$ treated with the unc-22 antibody. $(b, d)$ Arrows indicate the edge of a nonrevertant muscle cell. Note that the unc-22-expressing cell in $c$ has better organized A-bands than the nonrevertant cell (see also Fig. $6 \mathrm{c}$ ). Bar, $10 \mu \mathrm{m}$.

timated $14-\mathrm{kb}$ transcript. The gene may be larger still, as the $s t 139:: T c 1$ insertion site lies several kilobase pairs to the right of the small deficiencies. However, this allele is unusual in that the resultant phenotype is very weak and $\mathrm{Tc} 1$ sequences are not incorporated into the transcript. Until the $5^{\prime}$ end of the gene and its normal regulatory sequences are defined, we cannot rule out the possibility that several large introns or an unusually large regulatory region could place even the st139::Tc1 site within the boundaries of the gene. The large stable transcript detected indicates that most of the $20-\mathrm{kb}$ region is comprised of exons, which is not atypical of $C$. elegans genes (Kramer et al. 1982; Karn et al. 1983; Blumenthal et al. 1984; Spieth and Blumenthal 1985). Most of this mRNA must be coding sequence to yield the protein product or products of the gene greater than 500,000 daltons, as defined by the antibody and the analysis of the mutants.

The genetic analysis had also suggested that the unc-22 protein might be associated with the myosin heavy-chain product of the unc-54 locus. Only rare alleles of the unc-54 locus are able to suppress unc-22 mutants; no other loci were identified despite exhaustive screening (Moerman et al. 1982; D.G. Moerman, unpubl.). In addition, other rare alleles of the unc-54 locus partially mimic the unc-22 twitching phenotype. The two analyzed alleles of this class have small in-frame deletions that remove a section of the myosin rod (Dibb et al. 1985). The location of the unc-22 protein in the A-band, as determined by the antibody R11-3, supports the notion that the unc-54 and unc-22 proteins are associated, and studies on unc-54 missense mutants reveal that in mutants where the unc-54 protein is present but displaced from its normal A-band location, the unc-22 protein colocalizes with the unc-54 myosin (Fig. 7). This colocalization of the protein with unc-54 myosin in wild-type and mutant animals suggests that the unc-22 protein might bind directly to myosin or another component associated with it. Additional biochemical and morphological studies will be necessary to determine whether the unc-22 protein is indeed a component of the thick filament.

The R11-3 antibody not only detects reactive material in the body wall muscles but also in the anal, vulval, and pharyngeal muscles. All of these muscles, including the pharyngeal, also react with the R11-3 antibody after it has been affinity purified against the fusion polypeptide (D.G. Moerman et al., unpubl.). In unc-22 mutants the antibody staining is significantly reduced in all the muscles except the pharyngeal muscles, where the signal is identical to wild type. These observations on mutants, including genetic mosaics (Fig. 8), clearly indicate that staining of the body wall, anal, and vulval muscles in wild-type animals is due to the presence of the unc-22 protein in these cells. That unc-22 mutants have no effect on pharyngeal staining is in agreement with earlier studies showing that pharyngeal pumping and pharyngeal muscle structure were normal in multiple mutant isolates of unc-22 (Waterston et al. 1980). Apparently, an immunologically related protein is expressed in the pharynx, which is not the product of the unc-22 locus. Our inability to detect this second protein on Western blots is perhaps not surprising considering that pharyngeal muscles account for less than $5 \%$ of the total muscle mass. The weak residual staining of the body wall muscles observed in unc-22 mutants may be due to this second protein, or possibly even a third. Probing low-stringency genomic Southern blots with unc-22 fragments has not, as yet, revealed any strongly cross-hybridizing bands (D.G. Moerman et al., unpubl.). However, there is precedent for differential expression among gene family members in nematode muscle: Myosin heavy chains are encoded by four genes, two of which are expressed in the pharyngeal muscle and two of which are expressed in the body wall muscle (Epstein et al. 1974; Waterston et al. 1982; Karn et al. 1984; Miller et al. 1984).

The twitching aspect of the phenotype of unc-22 mutants has been used to infer that the unc-22 gene product is involved in the regulation of muscle contraction. The location of the protein in the A bands seems to rule out the possibility that the unc-22 protein is part of the muscle membrane or the sarcoplasmic reticulum. Its size also eliminates the possibility that it is one of the known thin-filament regulatory proteins or one of the myosin light chains. One intriguing possibility consis- 
tent with our findings is that the unc-22 protein may modulate myosin activity directly.

The intracellular location of the unc-22 protein is different from any of the few very large proteins identified in muscles of other animals. Z-nin (Suzuki et al. 1981) and zeugmatin (Mahler et al. 1985) are found in the Zline region of vertebrate muscle. Another large protein, nebulin, is only slightly smaller than the unc-22 protein, but its location in the N-2 line of the I band /Wang and Williamson 1980) makes it an unlikely analog. Titin is much larger in size, with a molecular weight of more than 1,000,000 (Wang et al. 1979; Trinick et al. 1984). Its apparent position within the sarcomere seems to depend on sarcomere length, but at resting length the immunoreactive groups are restricted to the A- to I-band junction. Another potentially large protein discovered recently is the product of the Duchenne's muscular dystrophy locus, which encodes an mRNA of about $16 \mathrm{~kb}$ (Monaco et al. 1986). However, no hybridization of the Duchenne's cDNA probes to the unc-22 genomic clones was detected even under low stringency (L. Kunkel, pers. comm.). In addition, partial sequences for both are known and they are not similar (unpubl.; L. Kunkel, pers. comm.). Whether any of these proteins or others are analogs of the unc-22 protein must await either the development of functional tests for these large proteins or more complete sequence comparisons.

The Tc1-induced alleles of unc-22 have been crucial at each step in our investigations and, in turn, our investigations of these alleles has revealed new aspects of Tc1 biology. The wide distribution of insertion sites helped to demonstrate the size of the gene. Although the disperse distribution of these insertions might suggest that Tc1 has little or no insertion site specificity, a much more limited set of insertion sites has been found for unc-54 (Eide and Anderson 1985), and our own sequence analysis of $\mathrm{Tc} 1$ insertion sites demonstrates that $\mathrm{Tc} 1$ has a preferred target sequence (Mori et al. 1987). Apparently the unc-22 gene is unusually rich in such sites.

The incorporation of $\mathrm{Tc} 1$ sequences in whole or in part into a full-length stable message aided in defining the region of the gene contributing to mature mRNA and is an unusual finding for transposable elements. The incorporation is independent of Tc1 orientation and largely independent of $\mathrm{Tc} 1$ position within the gene. In five of the six cases we studied, the insertions are in either orientation and are spread over a region of about 12 $\mathrm{kb}$. The only exception is the st139::Tc1 allele, where a normal-sized message is made.

The incorporation of a transposable element into a full-length RNA has been reported for a $D s$ insertion element into the alcohol dehydrogenase $(\mathrm{ADH})$ gene of maize (Doring et al. 1984), but, in general, insertion of a transposon into a gene results in a truncated message (Levis et al. 1984; Pirrotta and Brockl 1984). The intensity of signal from the full-length composite unc-22Tc1 transcript in the examples here suggests that very little, it any, termination is occurring within the Tc1 sequence, but we have not ruled out that termination occurs either at a variety of sites or results in an un- stable RNA that is not readily detected on Northern analysis. In fact, a few faint bands can be detected on long exposures of Northern transfers that are of a size consistent with their production via truncation within Tc1 (G.M. Benian and D.G. Moerman, unpubl.). Nevertheless, our results suggest that $\mathrm{Tc} 1$ contains either no, or only very weak, transcription-termination signals.

The incorporation of $\mathrm{Tc} 1$ sequences into the messages of genes with Tc1 insertions has several practical implications. First, it may serve to verify that a particular mRNA is the transcript of the gene under study, as was done here. Second, hybridization with a Tc1 probe of a Northern transfer of total RNA from a mutant strain might be useful in verifying that a mutation represents a Tc1 insertion. Such a composite RNA might even be used as an aid in cloning the gene in unusual circumstances. At present, we do not know how often Tc1 insertions will result in a composite mRNA. Results from an analysis of three unc-15::Tc1 alleles reveal that none of these mutations generates a hybrid message (R.P. Anderson, S. Rioux, and R.H. Waterston, unpubl.). Recent sequence analysis of these mutations (S. Rioux and R.H. Waterston, unpubl.) and of the paramyosin gene $(\mathrm{H}$. Kagawa, pers. comm.) suggests that these insertions lie near the $5^{\prime}$ end of the gene. These alleles are non-null alleles and may be analogous to the st139 allele. On the other hand, Tc1 insertions into tra-2 result in a transcript larger than wild type (P. Okkema and J. Kimble, pers. comm.).

A puzzling aspect of the unc-22::Tc1 alleles is that they are all phenotypically milder in their effects than are amber alleles or other likely null alleles. This is particularly noticeable at the level of muscle structure (see Figs. 6 and 7; Moerman and Waterston 1984). Previously, we postulated that the insertions might be in introns where they could be processed out (Moerman and Waterston 1984). Instead, the Tc1 sequences are incorporated into the stable transcript, and in the case of st 136::Tc1, a likely truncated peptide has been found. Furthermore, the integration sites of the $s t 136:: T c 1$ and st $137:: T c 1$ alleles lie within long open reading frames, not introns (I. Mori, G.M. Benian, and D.G. Moerman, unpubl.). Another possible explanation is that somatic excision of Tc1, which results in the appearance of several percent of the signal at the size of the wild-type band, could result in the production of sufficient protein to yield a weak phenotype. However, the unc-22 product appears to be cell autonomous, and only very rare cells show restoration of near normal levels of antibody-reactive material. Apparently, many of the somatic excision events, as judged by Southern analysis, must produce out-of-frame deletions or unstable, nonfunctional polypeptides. Another explanation is suggested by our present data: perhaps, the truncated polypeptide detected in st136::Tc1 animals (Fig. 5) is sufficient to produce discernible lattice organization but is unable to inhibit twitching. In severe alleles, lattice structure is disrupted more severely (Moerman and Waterston 1984). This possibility of different functional domains within the unc-22 locus is supported by partial sequence anal- 
ysis currently under way (J. Kiff, I. Mori, R.H. Waterston, and G.M. Benian, unpubl.).

The tentative assignment of unc-22 to the set of genes affecting the thick filament is significant. In addition to unc-22, the genes for both myosin heavy-chain isoforms and paramyosin have been discovered and subjected to a combined molecular and genetic analysis. The genes for the myosin light chains have been cloned $(\mathrm{C}$. Cummins and P. Anderson, pers. comm/ and, once localized to the genetic map, may also be subjected to genetic analysis. In addition, several genes have tentatively been assigned to the thick filament by genetic criteria, including unc-87, unc-82, and unc-89 (Waterston et al. 1980). Mutator-induced alleles of both unc-87 and unc-89 are available, and efforts are under way to recover DNA for these genes (D.G. Moerman et al., unpubl.). A thorough study of these and other genes yet to be discovered may provide us with a complete picture of thick filament assembly and function.

\section{Materials and methods}

\section{Growth and description of nematode strains}

Stock maintenance and strain growth for protein and nucleic acid preparations were as described in Brenner (1974) and Sulston and Brenner (1974). All unc-22::Tc1 mutants were isolated in either the BO strain of C. elegans var. Bergerac (Nigon 1949; Liao et al. 1983; Moerman and Waterston 1984) or in strains derived from crosses between $\mathrm{BO}$ and the $\mathrm{N} 2$ strain of $C$. elegans var. Bristol (Brenner 1974).

\section{Nucleic acid procedures}

High-molecular-weight nematode genomic DNA was isolated following the protocol of Wills et al. (1983). Standard methods were used for restriction digestion, gel electrophoresis, and Southern blotting (Southern 1975; Maniatis et al. 1982) DNA probes were labeled by nick translation (Rigby et al. 1977), and hybridization conditions were as described by Goodman et al. (1977). DNA clones used for localizing the unc-22::Tc1 inserts included $\lambda D M 17, \lambda D M 20$, and $\lambda$ DM22 (Moerman et al. 1986), which span the $30-\mathrm{kb}$ unc-22 region. In addition to these clones, several single SacI and BgIII fragments from unc-22, cloned into pucl 8 or puc19 (Yanish-Perron et al. 1985), were used as hybridization probes. Methods for growth and for DNA isolation from these phage and plasmid clones have been described (Karn et al. 1980; Maniatis et al. 1982).

Total RNA was prepared by a modification of the guanidine hydrochloride method of Chirgwin et al. (1979). A mixed population of nematodes was harvested from five $100-\mathrm{mm}$ petri dishes, washed to remove $E$. coli, and frozen at $-70^{\circ} \mathrm{C}$. Worms were ground in liquid nitrogen for $10 \mathrm{~min}$, using a mortar and pestle, and lyophilized for $5 \mathrm{hr}$. This powder was added to $4 \mathrm{ml}$ of a solution containing $6 \mathrm{M}$ guanidine hydrochloride, $0.5 \%$ Sarkosyl, 0.1 M 2-mercaptoethanol, and $0.1 \%$ antifoam A emulsion (Sigma, St. Louis, MO), pH 7.0, and vortexed for $80 \mathrm{sec}$. Debris was removed by centrifugation at $8000 \mathrm{rpm}$ in a Sorvall SS-34 rotor for $10 \mathrm{~min}$. The supernatant was then layered onto a $1.25-\mathrm{ml} \mathrm{CsCl}$ pad [5.7 M CsCl, 0.1 M EDTA, pH 7.0] and centrifuged in a Sorvall AH-650 rotor at $36,000 \mathrm{rpm}$ for $13 \mathrm{hr}$. The supernatant was discarded, and the pellet was resuspended in $0.3 \mathrm{ml}$ of guanidine hydrochloride solution (described above) by pipetting and heating at $65^{\circ} \mathrm{C}$ for $5 \mathrm{~min}$. The RNA was ethanol- precipitated, washed with absolute ethanol, and dissolved in $0.1-0.3 \mathrm{ml}$ of a solution containing $10 \mathrm{mM}$ Tris and $0.1 \mathrm{~mm}$ EDTA at $\mathrm{pH} 8$.

Fifteen micrograms of total RNA was electrophoresed through $0.7 \%$ agarose-formaldehyde gels (Maniatis et al. 1982) and transferred to nitrocellulose filters (Thomas 1980; Schleicher and Schuell, Inc., Keene, NH|. Filters were pre-hybridized for several hours at $42^{\circ} \mathrm{C}$ in $50 \%$ formamide, $5 \times \mathrm{SSC}$, $0.1 \% \mathrm{SDS}$, and $100-200 \mathrm{mg} / \mathrm{ml}$ denatured calf thymus DNA. This solution was discarded, and the filters were hybridized for $16 \mathrm{hr}$ at $42^{\circ} \mathrm{C}$ to ${ }^{32} \mathrm{P}$-labeled DNA or RNA probes in the same buffer, with the addition of dextran sulfate to $10 \%$. Extensive washings were done, initially in $2 \times$ SSC and $0.1 \%$ SDS at room temperature, and then in $0.1 \times \mathrm{SSC}$ and $0.1 \%$ SDS at $55-60^{\circ} \mathrm{C}$. Nitrocellulose filters were blotted dry and then exposed to Kodak XAR-2 film with an intensifying screen (DuPont Cronex Lightning-Plus, Dupont Co., Wilmington, DE) for $1-5$ days at $-70^{\circ} \mathrm{C}$.

To look for unc-22-encoded RNA, nick-translated $\lambda$ and plasmid clones (described above) were used as hybridization probes. For determining the direction of unc-22 transcription, we used strand-specific M13 probes (Brown et al. 1982), which were derived from a 1.1-kb EcoRV fragment near the st136::Tc1 insert (Moerman et al. 1986). The vector used to clone these fragments was mWB3295 (Barnes and Bevan 1983). A 1.6-kb EcoRV Tc1 fragment from pDM4 (Moerman et al. 1986) was nick-translated and used to probe the Northern blot shown in Figure 4 . To determine the orientation of Tc1 within the composite unc-22-Tc1 transcripts, labeled RNA was prepared from two SP6 recombinants that contain Tc1 in opposite orientation (Zinn et al. 1983). The myosin heavy-chain gene used for probing Northern blots was the $2.8-\mathrm{kb}$ BamHI fragment of unc-54 (Karn et al. 1980).

\section{Generation of the unc-22 fusion protein and antibody production}

The $\lambda$ vector $\lambda$ gt 11 (Young and Davis 1983) was modified by oligonucleotide mutagenesis in order to eliminate the SacI restriction site outside of the $\beta$-galactosidase gene, thereby making the SacI site in the gene unique (R.J. Barstead and R.H. Waterston, unpubl.). Partial sequencing of a portion of the unc-22 gene, as depicted in Figure 1, allowed us to identify a $\mathrm{SacI}$ fragment that would produce an in-frame fusion between the $\beta$-galactosidase of the modified vector, $\lambda R B 1$, and this portion of unc-22.

The clone containing the unc-22 insert, $\lambda L S 1$, was used to establish a lysogen in the E. coli strain Y1089 (Young and Davis 1983). The phage can be induced by a heat pulse at $42^{\circ} \mathrm{C}$ to initiate a lytic cycle in this strain; however, the amber mutation $\mathrm{S} 100$ in the phage $\mathrm{S}$ gene prevents lysis of the cells. The lysogenic strain was grown at $30^{\circ} \mathrm{C}$ to an $\mathrm{OD}_{600}$ of 0.25 in $\mathrm{L}$ broth. The culture was then transferred to a $42-44^{\circ} \mathrm{C}$ water bath and grown for $15 \mathrm{~min}$ after its temperature reached the temperature of the bath. Isopropal- $\beta$-D-thiogalactopyranoside (IPTG) was added to $1 \mathrm{mM}$, and growth was continued at $38^{\circ} \mathrm{C}$ for $1 \mathrm{hr}$. The cells were collected by centrifugation, resuspended in breaking buffer $\left[50 \mathrm{mM} \mathrm{NaH} \mathrm{PO}_{4}, \mathrm{pH} 7.4,50 \mathrm{mM} \mathrm{NaCl}, 1\right.$ mM EDTA, $1 \mathrm{~mm}$ phenylmethylsulfonyl flouride (PMSF), $0.5 \mathrm{M}$ $\beta$-mercaptoethanol, and a mixture of protease inhibitors], and sonicated. The solution was spun at $18 \mathrm{~K}$ for $15 \mathrm{~min}$, at $4^{\circ} \mathrm{C}$ in a Sorvall SS-34 rotor. $\mathrm{NH}_{4} \mathrm{SO}_{4}$ was added to $35 \%$.

The $\mathrm{NH}_{4} \mathrm{SO}_{4}$ precipitate containing the unv-22 fusion protein was collected by centrifugation. The $155-\mathrm{kD}$ fusion protein, first identified by its reaction with an anti- $\beta$-galactosidase serum (not shown; Cappel Laboratories), was further purified 
by preparative SDS-PAGE (Laemmli 1970). Samples were run on $5 \%$ polyacrylamide gels, which were fixed and stained using standard procedures. The band containing the fusion protein was excised, neutralized, and passed through a French Press in $0.15 \mathrm{M} \mathrm{NaH}_{2} \mathrm{PO}_{4}$ (pH 7.4). The disrupted gel was then emulsified with two volumes of adjuvant by sonication. A New Zealand white rabbit was immunized with three subcutaneous injections over the course of a month with $\sim 50 \mu \mathrm{g}$ of fusion protein/injection. Immune serum was collected 7 days after the last injection. Anti- $\beta$-galactosidase activity was eliminated by adsorption to E. coli $\beta$-galactosidase (Sigma), coupled to cyanogen bromide (CNBr)-activated Sepharose (Sigma).

\section{Western transfer procedures}

To prepare protein samples, $0.1 \mathrm{~g}$ of freshly grown nematodes was suspended in $1 \mathrm{ml}$ of a solution containing $50 \mathrm{~mm} 2$-aminoethanol (pH 11), $5 \mathrm{~mm}$ dithiothreitol (DTT), $2 \mathrm{mM}$ EDTA, and I mM PMSF. The samples were then heated in a microwave oven for $25 \mathrm{sec}$ and transferred to a boiling water bath for $3 \mathrm{~min}$. Laemmli sample buffer $(1 \mathrm{ml})$ was added to each, and the samples were immediately loaded onto a $5 \%$ acrylamide-SDS gel (Laemmli 1970). The gels were either stained with $0.05 \%$ Coomassie Brilliant Blue R-250 using standard conditions or transferred electrophoretically to a nitrocellulose filter (Towbin et al. 1979). Transfer conditions were as described by Francis and Waterston (1985), except the electrode buffer contained $0.1 \%$ SDS. After electroblotting, the nitrocellulose filters were preincubated for $15 \mathrm{~min}$ in Tris-buffered saline (TBS: $50 \mathrm{~mm}$ Tris- $\mathrm{HCl}, \mathrm{pH} 7,150 \mathrm{~mm} \mathrm{NaCl}$ ) with $0.1 \%$ Tween- 20 (Batteiger et al. 1982) and 5\% nonfat dried milk (Johnson et al. 1984) as blocking agents. Filters were then incubated with gentle shaking for $1 \mathrm{hr}$ in a sealed plastic bag containing this buffer and a 170-fold dilution of the R11-3 serum. After washing away unbound antibody with the same buffer, the filters were incubated with $1 \mu \mathrm{Ci}$ of affinity-purified ${ }^{125}$ I-labeled protein $\mathrm{A}$ (Amersham, Arlington Heights, IL) for $1 \mathrm{hr}$. Once again, the filters were washed, as described above, and exposed at $-70^{\circ} \mathrm{C}$ to Kodak XAR-2 film with an intensifying screen.

\section{Immunofluorescence techniques}

Nematodes were partially sheared in a French Press, according to the procedure of Francis and Waterston (1985), in the following rigor buffer: $100 \mathrm{mM} \mathrm{KCl}, 10 \mathrm{mM} \mathrm{KH}{ }_{2} \mathrm{PO}_{4}(\mathrm{pH} 7.0), 2$ $\mathrm{mM} \mathrm{MgCl}_{2}, 1 \mathrm{~mm}$ EDTA, $1 \mathrm{~mm}$ DTT, and $1 \mathrm{~mm}$ PMSF. They were washed twice in rigor buffer containing $1 \%$ NP-40 and fixed at room temperature for $3 \mathrm{hr}$ to overnight in $3 \%$ formaldehyde made up by dilution of formalin in phosphate-buffered saline (PBS) (pH 7), with the addition of $5 \mathrm{~mm}$ EDTA. The monoclonal antibody DM28.2 is specific for the unc-54 myosin heavy-chain peptide and is described in Miller et al. (1983). The monoclonal antibody DM5-8 is similar to DM28.2 (D.M. Miller, pers. comm.). Tetramethylrhodamine isothiocyanateconjugated goat-anti-mouse and fluorescein isothyocyanateconjugated goat-anti-rabbit secondary antibodies were obtained from Jackson Immunoresearch Labs, Inc. (Avondale, Pennsylvania). Antibody incubations were done as in Francis and Waterston (1985). Stained specimens were viewed with a Zeiss Universal microscope (Carl Zeiss, Inc., Thornwood, New York), equipped with epifluorescent illumination. Photomicrographs were prepared as in Francis and Waterston (1985).

\section{Acknowledgments}

The authors gratefully acknowledge Ross Francis for his advice regarding protein and immunochemical methods. We thank Carol Trent for providing three unc-22 internal deficiency strains, Kuan Wang for his gift of purified titin and nebulin, David Miller for providing a monoclonal antibody to the myosin heavy chain of unc-54, and Wayne Barnes for providing the plasmid mWB3295. We thank Eric Ward for introducing us to dideoxy sequencing. We would also like to thank the following people for allowing us to cite their unpublished results: Hiro Kagawa and Jon Karn, Stephen Rioux, Louis Kunkel, Claudia Cummins and Phil Anderson, Ikue Mori, Jane Kiff, and Peter Okkema and Judith Kimble. Secretarial assistance was provided by Kay Webb. R.J.B. was supported by a postdoctoral fellowship from the Muscular Dystrophy Association. This research was supported by U.S. Public Health Service grant GM23883 and a Muscular Dystrophy Association Jerry Lewis Neuromuscular Research Center grant to R.H.W.

\section{References}

Barnes, W.M. and M. Bevan. 1983. Kilo-sequencing: An ordered strategy for rapid DNA sequence data acquisition. Nucleic Acids Res. 11: 349-368.

Batteiger, B., W.J. Newhall, and R.R. Jones. 1982. Use of Tween 20 as a blocking agent in the immunological detection of proteins transferred to nitrocellulose membranes. I. Immunol. Methods 55: 297-307.

Blumenthal, T., M. Squire, S. Kirtland, J. Cane, M. Donegan, J. Spieth, and W. Sharrock. 1984. Cloning of a yolk protein gene family from Caenorhabditis elegans. I. Mol. Biol. 174: $1-18$.

Brenner, S. 1974. The genetics of Caenorhabditis elegans. Genetics 77: 71-94.

Brown, D.M., J. Frampton, P. Goelet, and J. Karn. 1982. Sensitive detection of RNA using strand-specific Ml3 probes. Gene 20: 139-144.

Chirgwin, J.M., A.E. Przybyla, R.J. MacDonald, and W.J. Rutter. 1979. Isolation of biologically active ribonucleic acid from sources enriched in ribonuclease. Biochemistry 18: 52945299.

Coulson, A., J. Sulston, S. Brenner, and J. Karn. 1986. Toward physical map of the genome of the nematode Caenorhab ditis elegans. Proc. Natl. Acad. Sci. 83: 7821-7825.

Dibb, N.J., D.M. Brown, J. Karn, D.G. Moerman, S.L. Bolten, and R.H. Waterston. 1985. Sequence analysis of mutations that affect the synthesis, assembly, and enzymatic activity of the unc-54 myosin heavy chain of Caenorhabditis elegans. I. Mol. Biol. 183: 543-551.

Doring, H.P., M. Freeling, S. Hake, M.A. Johns, R. Kunze, A. Merchelbach, F. Salamini, and P. Starlinger. 1984. A Ds-mutation of the Adh1 gene in Zea mays L. Mol. Gen. Genet. 193: 199-204.

Eide, D. and P. Anderson. 1985. The gene structure of spontaneous mutations affecting a Caenorhabditis elegans myosin heavy chain gene. Genetics 109: 67-69.

Emmons, S.W. and L. Yesner. 1984. High frequency excision of transposable element $\mathrm{Tc} 1$ in the nematode Caenorhabditis elegans is limited to somatic cells. Cell 36: 599-605.

Epstein, H.F., R.H. Waterston, and S. Brenner. 1974. A mutant affecting the heavy chain of myosin in C. elegans. I. Mol. Biol. 90: 291-300.

Francis, G. and R. Waterston. 1985. Muscle organization in Caenorhabditis elegans: Localization of proteins implicated in thin filament attachment and I-band organization. $J$. Cell Biol. 101: 1532-1549.

Goodman, H.M., M.V. Olson, and B.D. Hall. 1977. Nucleotide sequence of a mutant eukaryotic gene: The yeast tryosine- 
inserting ochre suppressor sup4-0. Proc. Natl. Acad. Sci. 74: 5453-5457.

Greenwald, I. 1985. lin-12, a nematode homeotic gene, is homologous to a set of mammalian proteins that includes growth factor. Cell 43: 583-590.

Johnson, D.A., J.W. Gautsch, J.R. Sportsman, and J.H. Elder. 1984. Improved techniques utilizing nonfat dry milk for analysis of proteins and nucleic acids transferred to nitrocellulose. Gene Anal. Technol. 1: 3-8.

Karn, J., S. Brenner, and L. Barnett. 1983. Protein structural domains in the Caenorhabditis elegans unc-54 myosin heavy chain gene are not separated by introns. Proc. Natl. Acad. Sci. 80: 4253-4257.

Karn, J., N.J. Dibb, and D.M. Miller. 1984. Cloning nematode myosin genes. In Cell and muscle motility VI (ed. J. Shay) pp. 185-237. Plenum, New York.

Karn, J., S. Brenner, L. Barnett, and G. Cesareni. 1980. Novel bacteriophage $\lambda$ cloning vector. Proc. Natl. Acad. Sci. 77: 5172-5176.

Kramer, J.M., G.N. Cox, and D. Hirsh. 1982. Comparisons of the complete sequences of two collagen genes from Caenorhabditis elegans. Cell 30: 599-606.

Laemmli, U.K. 1970. Cleavage of structural proteins during the assembly of the head of bacteriophage T4. Nature 227: 680685.

Landel, C.P., M. Krause, R.H. Waterston, and D. Hirsh. 1984. DNA rearrangements of the actin gene cluster in Caenorhabditis elegans accompany reversion of three muscle mutants. J. Mol. Biol. 180: 497-513.

Levis, R., K. O'Hare, and G.M. Rubin. 1984. Effects of transposable element insertions on RNA encoded by the white gene of Drosophila. Cell 38: 471-481.

Lewis, J.A., C.-H. Wu, J.H. Levine, and H. Berg. 1980. Levamisole resistant mutants of the nematode Caenorhabditis elegans appear to lack pharmacological acetylcholine receptors. Neuroscience 5: 967-989.

Liao, L.W., B. Rosenzweig, and D. Hirsh. 1983. Analysis of a transposable element in Caenorhabditis elegans. Proc. Natl. Acad. Sci. 80: 3583-3589.

Losson, R. and F. LaCroute. 1979. Interference of nonsense mutations with eukaryotic messenger RNA stability. Proc. Natl. Acad. Sci. 76: 5134-5137.

MacLeod, A.R., R.H. Waterston, and S. Brenner. 1977a. An internal deletion mutant of a myosin heavy chain in $C$. elegans. Proc. Natl. Acad. Sci. 74: 5336-5340.

MacLeod, A.R., R.H. Waterston, R.M. Fishpool, and S. Brenner. $1977 \mathrm{~b}$. Identification of the structural gene for a myosin heavy chain in C. elegans. J. Mol. Biol. 114: 133-140.

Mahler, P.A., G.F. Cox, and S.J. Singer. 1985. Zeugmatin: A new high molecular weight protein associated with $Z$ lines in adult and early embryonic striated muscle. I. Cell Biol. 101: $1871-1883$.

Maniatis, T., E.F. Fritsch, and J. Sambrook. 1982. Molecular cloning: A laboratory manual. Cold Spring Harbor Laboratory, Cold Spring Harbor, New York.

Miller, D.M., I. Ortiz, G.C. Berliner, and H.F. Epstein. 1983. Differential localization of two myosins within nematode thick filaments. Cell 34: 477-490.

Miller, D.M., F.R. Stockdale, and J. Karn. 1986. Immunological identification of the genes encoding four myosin heavy chain isoforms of Caenorhabditis elegans. Proc. Natl. Acad. Sci. 83: 2305-2309.

Moerman, D.G. 1980. "Genetic analysis of the unc-22 region in Caenorhabditis elegans." Dissertation. Simon Fraser University, Burnaby, B.C.

Moerman, D.G. and D.L. Baillie. 1979. Genetic organization in
Caenorhabditis elegans: Fine-structure analysis of the unc-22 gene. Genetics 91: 95-103.

Moerman, D.G. and R.H. Waterston. 1984. Spontaneous unstable unc-22 IV mutations in Caenorhabditis elegans var. Bergerac. Genetics 108: 859-877.

Moerman, D.G., S. Plurad, R.H. Waterston, and D.L. Baillie. 1982. Mutations in the unc-54 myosin heavy chain gene of Caenorhabditis elegans that alter contractility but not muscle structure. Cell 29: 773-781.

Moerman, D.G., G.M. Benian, and R.H. Waterston. 1986. Molecular cloning of the muscle gene unc-22 in Caenorhabditis elegans by Tcl transposon tagging. Proc. Natl. Acad. Sci. 83: 2579-2583.

Monaco, A.P., R.L. Neve, C. Colletti-Feener, C.J. Bertelson, D.M. Kurnit, and L.M. Kunkel. 1986. Isolation of candidate cDNAs for portions of the Duchenne muscular dystrophy gene. Nature 323: 646-650.

Mori, I., G.M. Benian, D.G. Moerman, and R.H. Waterston. 1987. Transposable element Tcl of Caenorhabditis elegans recognizes specific target sequences for integration. Proc. Natl. Acad. Sci. (in press).

Nigon, V. 1949. Les modalites de la reproduction et le determinisme du sexe chez quelques nematodes libres. Ann. Sci. Natl. Zool. 11: 1-132.

Pirrotta, V. and C. Brockl. 1984. Transcription of the Drosophila white locus and some of its mutants. EMBO $J$. 3(3): 563-568.

Rigby, P.W.J., M. Dieckmann, C. Rhodes, and P. Berg. 1977. Labeling deoxyribonucleic acid to high specific activity in vitro by nick translation with DNA polymerase I. I. Mol. Biol. 113: 237-251.

Rogalski, T.M. and D.L. Baillie. 1985. Genetic organization of the unc-22 IV gene and the adjacent region in C. elegans. Mol. Gene. Genet. 201: 409-414.

Rosenzweig, B., L.W. Liao, and D. Hirsh. 1983. Sequence of the C. elegans transposable element Tcl. Nucleic Acids Res. 11(12): 4201-4209.

Rowland, L.J. and J.N. Strommer. 1985. Insertion of an unstable element in an intervening sequence of maize $A d h 1$ affects transcription but not processing. Proc. Natl. Acad. Sci. 82: $2875-2879$.

Southern, E.M. 1975. Detection of specific sequences among DNA fragments separated by gel electrophoresis. J. Mol. Biol. 98: 503-517.

Spieth, J. and T. Blumenthal. 1985. The Caenorhabditis elegans vitellogenin gene family includes a gene encoding a distantly related protein. Mol. Cell. Biol. 5(10): 2495-2501.

Sulston, J.E. and S. Brenner. 1974. The DNA of Caenorhabditis elegans. Genetics 77: 95-104.

Suzuki, A., M. Saito, A. Okitani, and Y. Nonami. 1981. Z-nin, a new high molecular weight protein required for reconstitution of the Z-disk. Agric. Biol. Chem. 45: 2535-2542.

Thomas, P.S. 1980. Hybridization of denatured RNA and small DNA fragments transferred to nitrocellulose. Proc. Natl. Acad. Sci. 77: 5201-5205.

Towbin, H., T. Staehelin, and J. Gordon. 1979. Electrophoretic transfer of proteins from polyacrylamide gels to nitrocellulose sheets: Procedure and some application. Proc. Natl. Acad. Sci. 76: 4350-4354.

Trinick, J., P. Knight, and A. Whiting. 1984. Purification and properties of native titin. J. Mol. Biol. 180: 331-356.

Wang, K. and C.L. Williamson. 1980. Identification of an N2 line protein of striated muscle. Proc. Natl. Acad. Sci. 77: $3254-3258$.

Wang, K., J. McClure, and A. Tu. 1979. Titin: Major myofibrillar components of striated muscle. Proc. Natl. Acad. Sci. 
76: $3698-3702$.

Waterston, R.H., R.M. Fishpool, and S. Brenner. 1977. Mutants affecting paramyosin in Caenorhabditis elegans. I. Mol. Biol. 111: 679-697.

Waterston, R.H., J.N. Thomson, and S. Brenner. 1980. Mutants with altered muscle structure in Caenorhabditis elegans. Dev. Biol. 77: 271-302.

Waterston, R.H., K.C. Smith, and D.G. Moerman. 1982. Genetic fine structure analysis of the myosin heavy chain gene unc-54 of Caenorhabditis elegans. J. Mol. Biol. 158: 1-15.

Wills, N., R.F. Gesteland, J. Karn, L. Barnett, S. Bolten, and R.H. Waterston. 1983. The genes sup-7 $X$ and sup-5 III of $C$. elegans suppress amber nonsense mutations via altered transfer RNA. Cell 33: 575-583.

Yanisch-Perron, C., J. Vieira, and J. Messing. 1985. Improved M13 phage cloning vectors and host strains: Nucleotide sequences of the M13mpl8 and pUC19 vectors. Gene 33: $103-119$.

Young, R.A. and R.W. Davis. 1983. Efficient isolation of genes by using antibody probes. Proc. Natl. Acad. Sci. 80: 11941198.

Zachar, Z., D. Davison, D. Garza, and P.M. Bingham. 1985. A detailed developmental and structural study of the transcriptional effects of insertion of the copia transposon into the white locus of Drosophila melanogaster. Genetics 111: 495-515.

Zengel, J.M. and H.F. Epstein. 1980. Identification of genetic elements associated with muscle structure of the nematode Caenorhabditis elegans. Cell Motil. 1: 73-97.

Zinn, K., D. DiMaio, and T. Maniatis. 1983. Identification of two distinct regulatory regions adjacent to the human B-interferon gene. Cell 34: 865-879. 


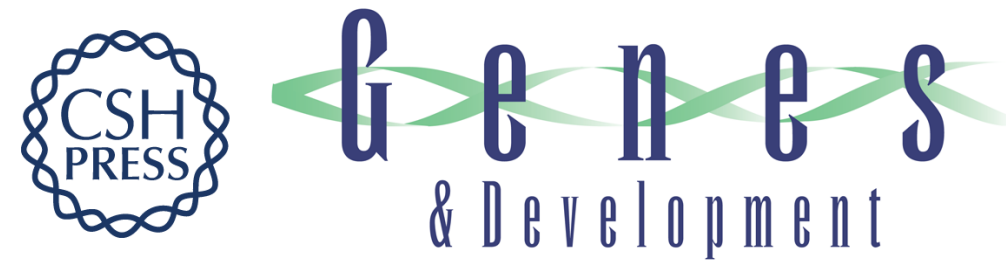

\section{Identification and intracellular localization of the unc-22 gene product of Caenorhabditis elegans.}

D G Moerman, G M Benian, R J Barstead, et al.

Genes Dev. 1988, 2:

Access the most recent version at doi:10.1101/gad.2.1.93

References This article cites 59 articles, 23 of which can be accessed free at: http://genesdev.cshlp.org/content/2/1/93.full.html\#ref-list-1

License

Email Alerting

Receive free email alerts when new articles cite this article - sign up in the box at the top Service right corner of the article or click here.

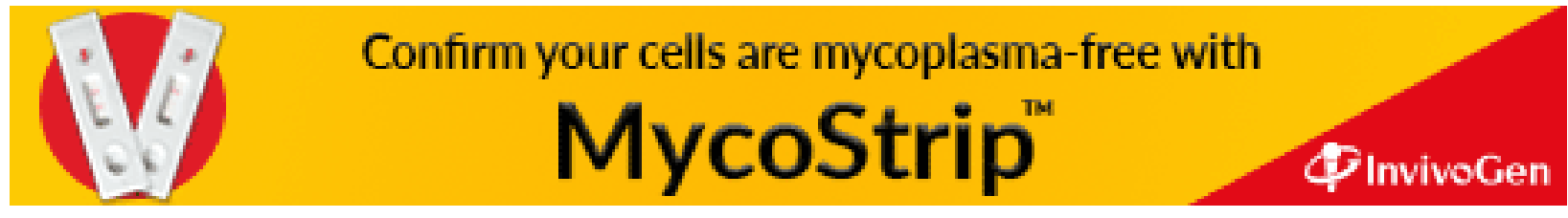

